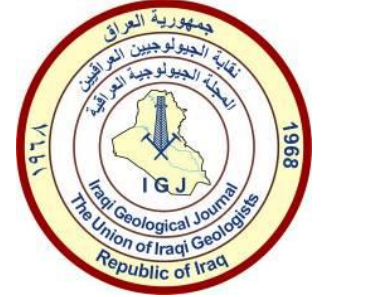

Iraqi Geological Journal

Journal homepage: https://www.igj-iraq.org

\title{
Using Pumping Tests and Two Techniques of the Water Balance to Assess the Aquifer Hydraulic Characteristics and the Groundwater Recharge of Shewasoor Sub-Basin Kirkuk, NE Iraq
}

\author{
Banaz Adeeb Fattah Agha ${ }^{1, *}$ and Omer S. Ibrahiem Al-Tamimi ${ }^{1}$ \\ Department of Applied Geology, College of Science, University of Kirkuk, Kirkuk, Iraq \\ Correspondence: banazkakai4@gmail.com
}

Received: 11 November 2021

Accepted: 20 November 2021

Published: 28 February 2022

\begin{abstract}
Shewasoor sub-Basin represents one of the hydrogeological sub-basins of the Lower Zab River and covers an area of $160 \mathrm{~km}^{2}$. It is located between longitude ( $44^{\circ} 31^{\prime} 23.9^{\prime \prime}-44^{\circ} 37^{\prime}$ $\left.75^{\prime \prime}\right)$ and latitudes ( $\left.35^{\circ} 45^{\prime} 28.9^{\prime \prime}-35^{\circ} 48^{\prime} 59^{\prime \prime}\right)$. The basin is bounded from the north and northeast by the Taqtaq anticline and Chamchamal anticline represents the western and southwest boundaries, while the southeast boundary is a surface water divide with the AlKhassah River sub-basin. The groundwater distribution levels and movement maps show that the water depths range between 414-862 $\mathrm{m}$ a.s.l, and it moves in line with the movement of water surface drainage, as it moves from the east, southeast, south, and southwest (recharge areas) towards the northwest regions, while the water depths vary from the ground level between relatively deep in the southwestern part to medium and shallow in the rest of the parts. An evaluation of the hydraulic characteristic and groundwater recharge by two techniques of the water balance for aquifers of the study area has been carried out. The results showed that the hydraulic properties, transmissivity value ranges between 5.6 - 169 $\mathrm{m}^{2} /$ day, the hydraulic conductivity values range between $0.67-5.1 \mathrm{~m} /$ day, and the storage coefficient values, ranging from the lowest value $(0.0013)$ to the highest value $(0.27)$. The results reflected that the types of the aquifers are unconfined and semi-confined as well as heterogeneous and anisotropic. after analyzing and calculating the climatological parameters of Koya meteorological station as the nearest station to the Shewassor area, showed the water surplus is equal to $333.94 \mathrm{~mm}$ which represent $53.8 \%$ of the annual rainfall value $(628.3 \mathrm{~mm})$ and the surface water is equal to $138.5 \mathrm{~mm}$ as a runoff. $199.44 \mathrm{~mm}$ $(31.74 \%)$ out of the annual rainfall is percolated to recharge the aquifers of Shewasoor, while water table fluctuation method WTF showed there are two zones of specific yield in the study area and the groundwater recharge is $232.06 \mathrm{~mm}$, so can be said that the $215.8 \mathrm{~mm}$ is the average of the groundwater recharge in Shewasoor sub-basin. Finally, and by using the groundwater flow net analyzing technique that the amount of groundwater discharged from the study area is about 12 million $\mathrm{m} 3$ (MCM) and the renewal groundwater storage is 19.42 million $\mathrm{m} 3$ (MCM), which means there is 7.39 million $\mathrm{m} 3$ is groundwater can be invested as a safe investment.
\end{abstract}

Keywords: Shewasoor sub-basin; Pumping test; Hydraulic properties; Water balance; Groundwater recharge 


\section{Introduction}

Water is very important for human activities, many regions around the world depending on groundwater which considered as one of the most important sources of fresh-water (AL-Hayali et al., 2021). The shortage of water resources, especially in the surface water, led to Iraq's tendency to exploit groundwater to meet its domestic, agricultural and industrial requirements. The irrigation return, rainfall infiltration, and the riverbed floods flow led to groundwater recharge in the region (Tizro et al., 2014). Efforts to control and monitor water sources and groundwater use have become indispensable for maintaining sustainable groundwater availability (Waspodo et al., 2020). Hydrogeological methods are among the important foundations for the development and management of groundwater resources and their exploitation. Therefore, groundwater must be invested based on an assessment of the hydrogeological conditions and hydraulic properties of the aquifer layers of water and their drainage and their relationship between them (Moharir et al., 2020). Groundwater in its natural state moves steadily and depends in its movement on several fixed hydraulic properties such as (hydraulic conduction, transmissivity and storage coefficient (Todd and Mays, 2004). hydrogeological properties are very beneficial in describing subsurface hydrology. (Mendosa et al. 2003) (Al-Naqash et al., 2003).

Shewasoor subbasin is located to the north eastern part of Iraq, far $40 \mathrm{Km}$ northeast of Kirkuk city, between longitudes ( $\left.44^{\circ} 31^{\prime} 23.9^{\prime \prime} \mathrm{E}-44^{\circ} 37^{\prime} 07.5^{\prime \prime} \mathrm{E}\right)$, and the latitudes ( $35^{\circ} 45^{\prime} 28.9^{\prime \prime} \mathrm{N}-35^{\circ} 48^{\prime} 59.1^{\prime \prime}$ $\mathrm{N}$ ), the elevation ranged between 438 - $879 \mathrm{~m}$. a.s.l, and covers about $160 \mathrm{~km}^{2}$, the Shewasoor Subbasin is bounded from north and northeast sides by Taqtaq Anticline, from west and southwest sides by Northern ChamChamal Anticline, and by topographic Surface water wear between Al-Khassa Sub-basin and the study area from south and southeast side's (Fig.1).

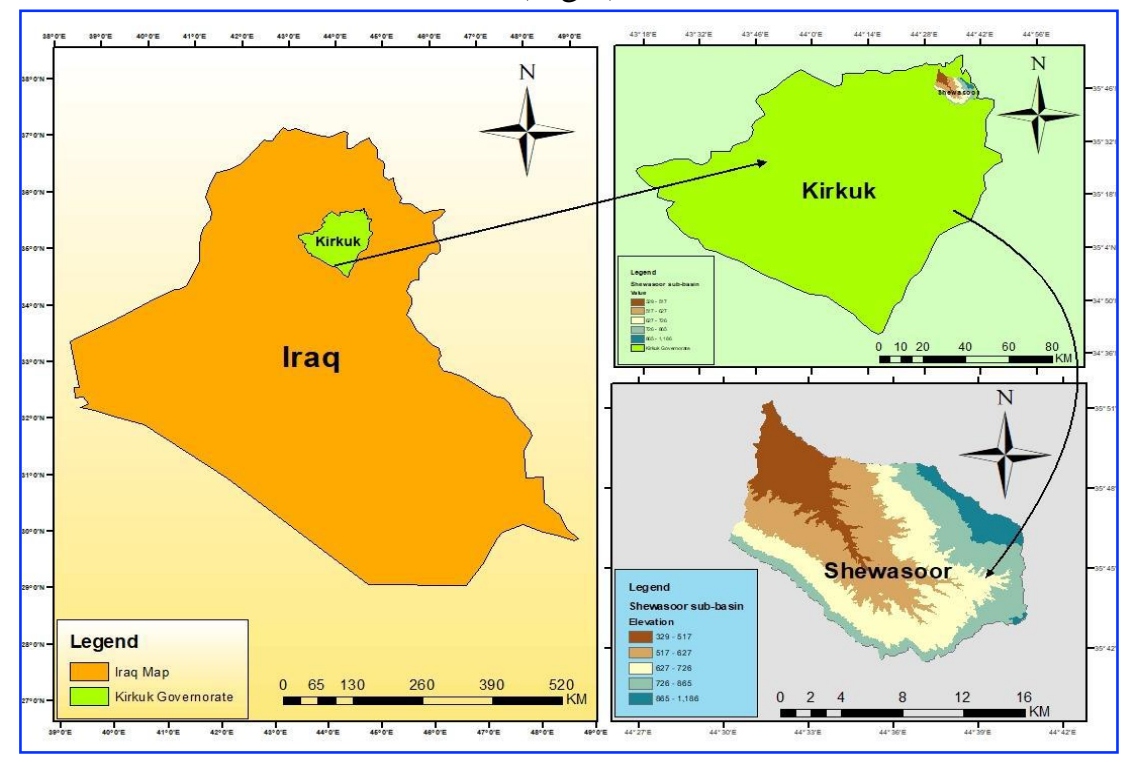

Fig.1. Topography and location of the study area

Hydrogeologically, the study area lies in the Foothill aquifer system in Altun Kopri-Koysanjaq Sub-system (Jassim and Goff, 2006). The Shewasoor dam lake is the main hydrological feature of the study area. The groundwater occurred in two aquifers: relatively deep groundwater within Bai- Hassan formation and shallow groundwater which is represented by quaternary deposits saturation thickness of the study area obtained from the geophysical section of the Italian report of Shewasoor dam (Engineering Consulting Bureau, 2010). The study area contains wells that people drilled inside farms or homes, which are less deep and smaller than government wells drilled in the region. The most wells which drilled are benefiting from the water of aquifer, which is scouted for several purposes such as agriculture, domestic, and etc (Ali and Al-Tamimi, 2019). The aim of this study depending on the 
pumping test in two methods, namely the climatic water-balance method and the groundwater level fluctuation change. Assessment the hydraulic characteristics (hydraulic conductivity, transmissivity, storage coefficient) of the aquifer and identify the type of aquifer in the Shewasoor Sub-basin, evaluating the renewal groundwater storage, determination the special distribution and the movement direction of the groundwater in the study area.

\section{Materials and Methods}

Groundwater monitoring and recording of water level changes in wells are carried out in the study area and the pumping test process was used to obtain the hydraulic properties (transmissivity, storage coefficient, hydraulic conduction) of groundwater aquifer, which give an indication about the velocity of water within the porous medium and its effect on the groundwater level (Hem, 1985). Twenty groundwater wells were monitored to measure the groundwater levels and the water tables which shown in Table 1 while pumping was tested on four wells distributed in study area in order to assess the hydraulic properties, as mentioned above the pumping test data were analyzed in the Aquifer Win - 32 software program, by using the Copper-Jacob and Hantush methods (Ali, 2020). The reason for choosing these wells 4 is that there are available wells and the difficulty of accessing other wells due to the ruggedness of the area and the lack of consent of the people of the area to conduct the experimental pumping process in their wells because most of the wells in the area are dug by the people of the area and not governmental.

Table 1. Basic data of the water well in the study area

\begin{tabular}{|c|c|c|c|c|c|}
\hline wells & Longitude & Latitude & Elevation (m. a. s. l) & Depth to water (m) & SWL (m a.s.l) \\
\hline W1 & $44^{\circ} 35^{\prime} 55^{\prime \prime}$ & $35^{\circ} 45^{\prime} 50^{\prime \prime}$ & 618 & 31.1 & 586.9 \\
\hline W2 & $44^{\circ} 33^{\prime} 04^{\prime \prime}$ & $35^{\circ} 45^{\prime} 58^{\prime \prime}$ & 609 & 18.55 & 590.45 \\
\hline W3 & $44^{\circ} 33^{\prime} 36^{\prime \prime}$ & $35^{\circ} 46^{\prime} 53^{\prime \prime}$ & 488 & 11.2 & 476.8 \\
\hline W4 & $44^{\circ} 33^{\prime} 47^{\prime \prime}$ & $35^{\circ} 45^{\prime} 51^{\prime \prime}$ & 580 & 32.05 & 547.95 \\
\hline W5 & $44^{\circ} 31^{\prime} 54^{\prime \prime}$ & $35^{\circ} 46^{\prime} 45^{\prime \prime}$ & 586 & 36.6 & 549.4 \\
\hline W6 & $44^{\circ} 31^{\prime} 23^{\prime \prime}$ & $35^{\circ} 46^{\prime} 42^{\prime \prime}$ & 580 & 29.5 & 550.5 \\
\hline W7 & $44^{\circ} 31^{\prime} 41^{\prime \prime}$ & $35^{\circ} 47^{\prime} 08^{\prime \prime}$ & 560 & 24.7 & 535.3 \\
\hline W8 & $44^{\circ} 33^{\prime} 05^{\prime \prime}$ & $35^{\circ} 47^{\prime} 51^{\prime \prime}$ & 438 & 2.55 & 435.45 \\
\hline W9 & $44^{\circ} 34^{\prime} 31^{\prime \prime}$ & $35^{\circ} 47^{\prime} 43^{\prime \prime}$ & 566 & 4.55 & 561.45 \\
\hline W10 & $44^{\circ} 35^{\prime} 57^{\prime \prime}$ & $35^{\circ} 47^{\prime} 56^{\prime \prime}$ & 618 & 28.15 & 589.85 \\
\hline W11 & $44^{\circ} 36^{\prime} 27^{\prime \prime}$ & $35^{\circ} 47^{\prime} 12^{\prime \prime}$ & 673 & 16 & 657 \\
\hline W12 & $44^{\circ} 37^{\prime} 05^{\prime \prime}$ & $35^{\circ} 47^{\prime} 13^{\prime \prime}$ & 713 & 25.65 & 687.35 \\
\hline W13 & $44^{\circ} 36^{\prime} 27^{\prime \prime}$ & $35^{\circ} 45^{\prime} 45^{\prime \prime}$ & 665 & 61 & 604 \\
\hline W14 & $44^{\circ} 39^{\prime} 40^{\prime \prime}$ & $35^{\circ} 45^{\prime} 54^{\prime \prime}$ & 879 & 7.25 & 871.75 \\
\hline W15 & $44^{\circ} 35^{\prime} 41^{\prime \prime}$ & $35^{\circ} 45^{\prime} 39^{\prime \prime}$ & 617 & 54.3 & 562.7 \\
\hline W16 & $44^{\circ} 36^{\prime} 08^{\prime \prime}$ & $35^{\circ} 45^{\prime} 39^{\prime \prime}$ & 649 & 24.65 & 624.35 \\
\hline W17 & $44^{\circ} 37^{\prime} 07^{\prime \prime}$ & $35^{\circ} 45^{\prime} 52^{\prime \prime}$ & 706 & 64 & 642 \\
\hline W18 & $44^{\circ} 33^{\prime} 48^{\prime \prime}$ & $35^{\circ} 48^{\prime} 56^{\prime \prime}$ & 510 & 23.3 & 486.7 \\
\hline W19 & $44^{\circ} 33^{\prime} 31^{\prime \prime}$ & $35^{\circ} 48^{\prime} 55^{\prime \prime}$ & 494 & 20.4 & 473.6 \\
\hline W20 & $44^{\circ} 32^{\prime} 56^{\prime \prime}$ & $35^{\circ} 48^{\prime} 59^{\prime \prime}$ & 477 & 28.25 & 448.75 \\
\hline
\end{tabular}


After that, the groundwater recharge for the aquifer of the study area has been calculated through using two common and important methods (Climatological water balance and water table fluctuation WTF) which are inserted within the water balance of the hydrological basin.

\section{Results and Discussion}

Depending on the basic data of water wells in the study area (Table 1) and drawing the groundwater flow net of shewasoor sub-basin (Fig.2), (the groundwater distribution levels and directions of the movements) showed that the water tables range between 414-862 $\mathrm{m}$ a.s.l, and the movements are from the east, southeast, south and southwest (recharge areas) towards the northwest regions. (Discharge areas) which is follow in this condition the surface water patterns of the study area while, the water depths vary from the ground level between relatively deep in the southwestern part (61) $\mathrm{m}$ to medium and shallow in the rest areas (2.5) $\mathrm{m}$. After analyzing the pumping test data, (Table 2), (Figs. 3 and 4), the result of the hydraulic characteristics showed there were some variations in the study area. The value of transitivity range between $5.6-169 \mathrm{~m}^{2} / \mathrm{d}$, the hydraulic conductivity values are varying from one place to another and range between $(0.67-5.1) \mathrm{m} / \mathrm{d}$ and values of storage coefficient, differ in the study area, where they range from the lowest value (0.0013) and the highest value (0.27) that shown in Table 3 . The variation of hydraulic characteristics values is reflected variation in lithology and the saturated thickness of the aquifers, which mean the heterogenic and an isotropic formation. The results of the pumping test of the selected wells within the study area indicate that the aquifer types are (Unconfined and Semi-Confined) also it is anisotropic and heterogenic. The values of the hydraulic parameters and saturation thickness which were listed in Table 3 and illustrated in Figs. 5, 6, 7 and 8.

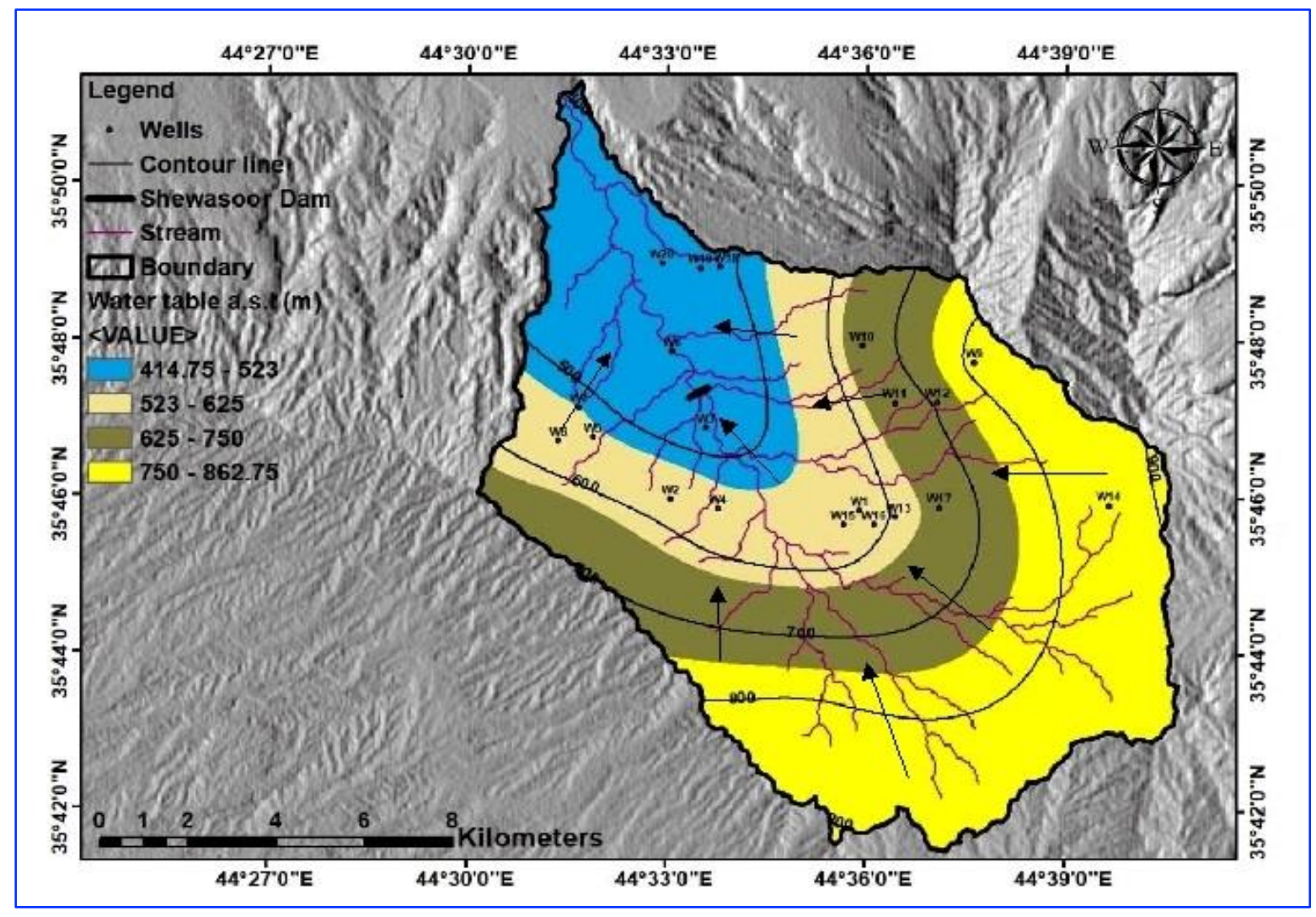

Fig.2. Equipotential lines and flow directions of the groundwater in the study area 
Table 2. Pumping tests data of the four wells in the study area

\begin{tabular}{lcccc}
\hline Time(min) & Drawdown(cm) & (Observationwell) & \multicolumn{2}{c}{ Drawdown(m) (Single well) } \\
\hline & W8 & W5 & W12 & W15 \\
2 & 1 & 1 & 2.5 & 2.1 \\
3 & 2.2 & 2.5 & 4.5 & 2.92 \\
4 & 3.3 & 3.5 & 6 & 3.7 \\
5 & 4 & 5 & 8 & 4.32 \\
10 & 5 & 6.5 & 9 & 6.64 \\
15 & 7 & 9 & 11 & 7.9 \\
20 & 8.2 & 10.5 & 13.1 & 9.2 \\
25 & 9.1 & 12 & 14 & 10 \\
30 & 9.75 & 13 & 15 & 11 \\
45 & 10.6 & 13.5 & 16.25 & 13 \\
60 & 12 & 15.5 & 17.5 & 14.8 \\
75 & 13.4 & 16.5 & 19.1 & 16.66 \\
90 & 14.25 & 17.25 & 20 & 17 \\
105 & 15 & 18 & 20.5 & 17.33 \\
120 & 15.9 & 18.5 & 21 & 17.5 \\
150 & 17 & 20 & 21 & 17.5 \\
180 & 17.5 & 21 & & \\
210 & 17.5 & 22 & & \\
\hline
\end{tabular}

Table 3. Wells number and their coordinate and the results of the methods $\mathrm{T}, \mathrm{K}$ and $\mathrm{S}$ in the study area.

\begin{tabular}{lccccccc}
\hline Wells & Long. & Lat. & T & B & Sc (Sy) & K & Well Type \\
\hline W8 & 459465 & 3961580 & 169 & 33 & 0.002 & 5.1 & Observation Well \\
W12 & 465484 & 3960390 & 6.1 & 9 & 0.132 & 0.67 & Single Well \\
W15 & 463363 & 3957500 & 5.6 & 8 & 0.278 & 0.7 & Single Well \\
W5 & 457673 & 3959560 & 141 & 30 & 0.0013 & 4.7 & Observation Well \\
Recharge of the area & & & & & & \\
\multicolumn{2}{l}{ Study area cover } & & & & & & \\
\hline
\end{tabular}

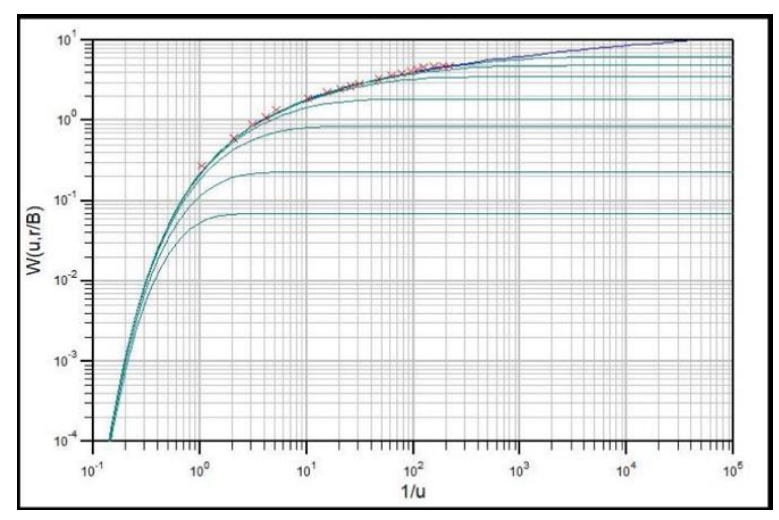

Well 8

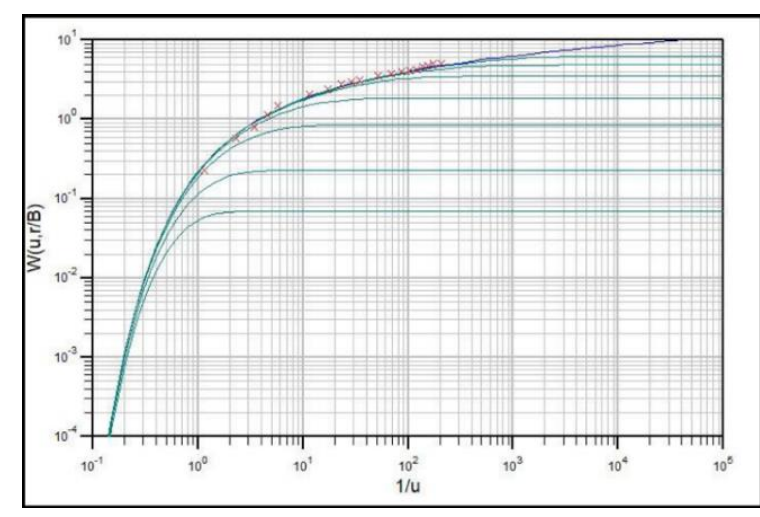

Well 5

Fig .3. Pumping test data analysis of W8 and W5 by Hantuosh method 


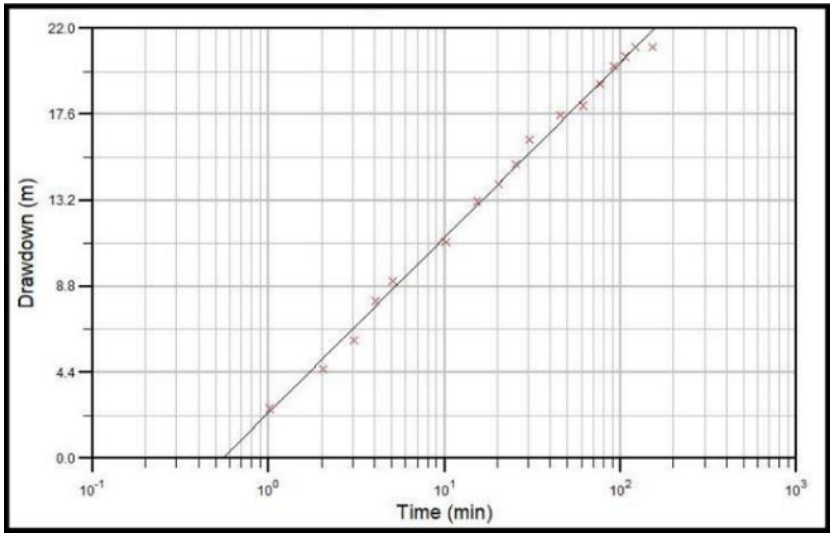

Well 12

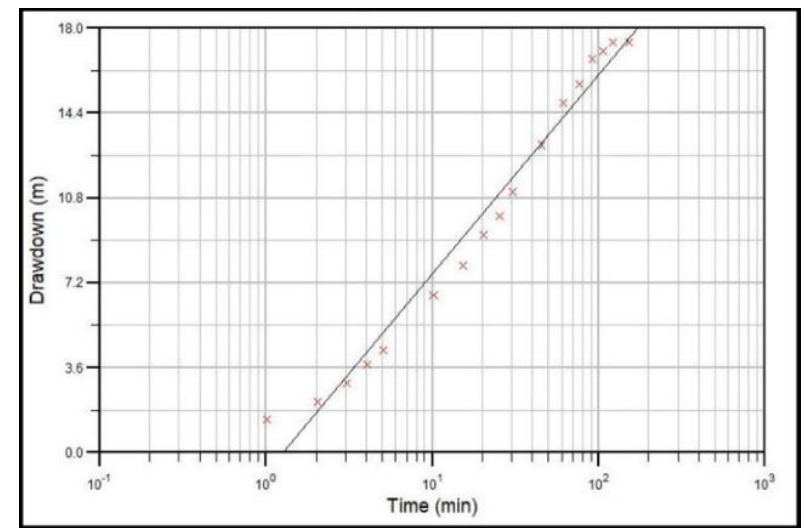

Well 15

Fig .4. Pumping test data analysis of W12 and W15 by Copper- Jacob method

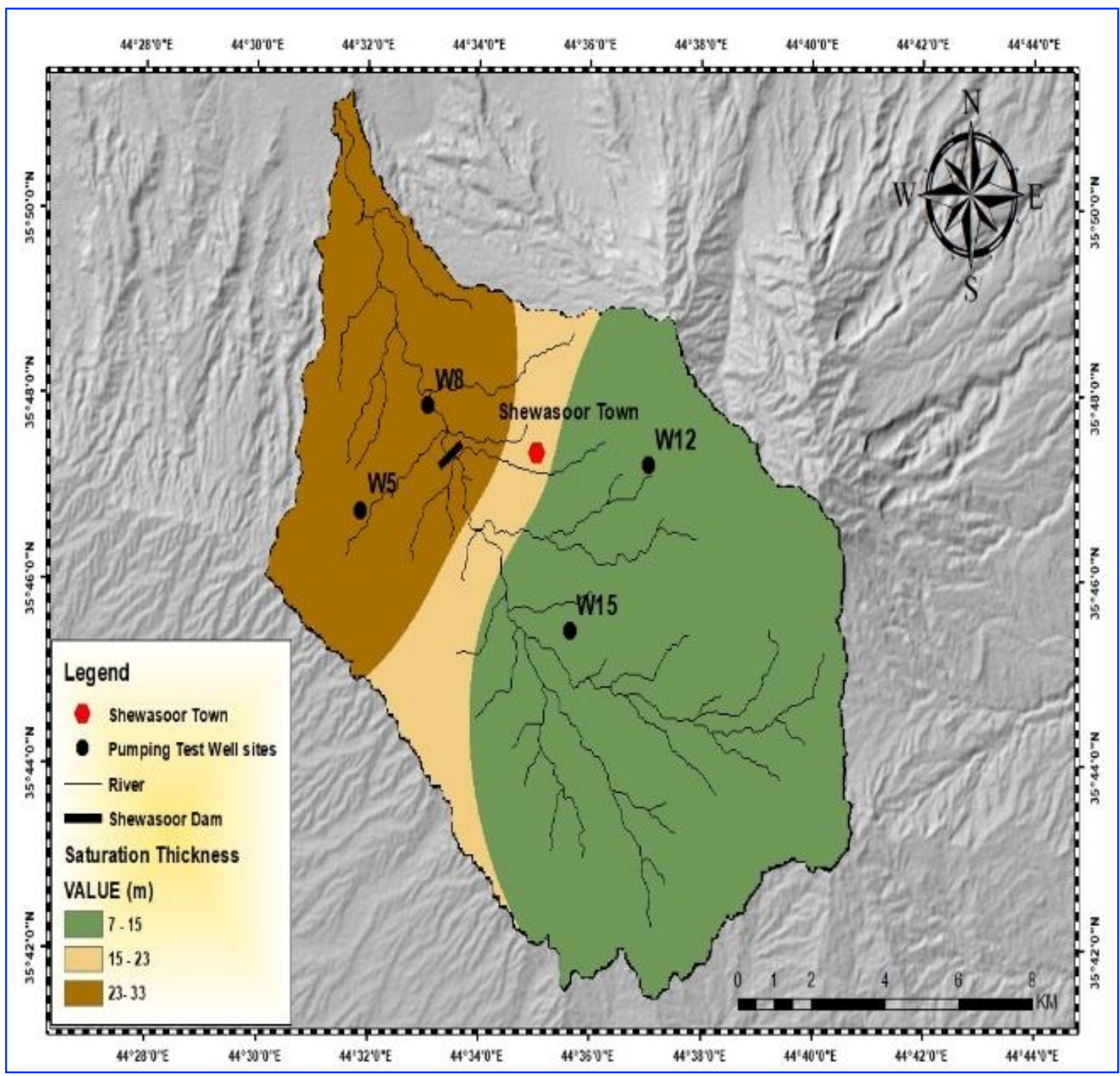

Fig .5. Saturated thickness map of the study area. 


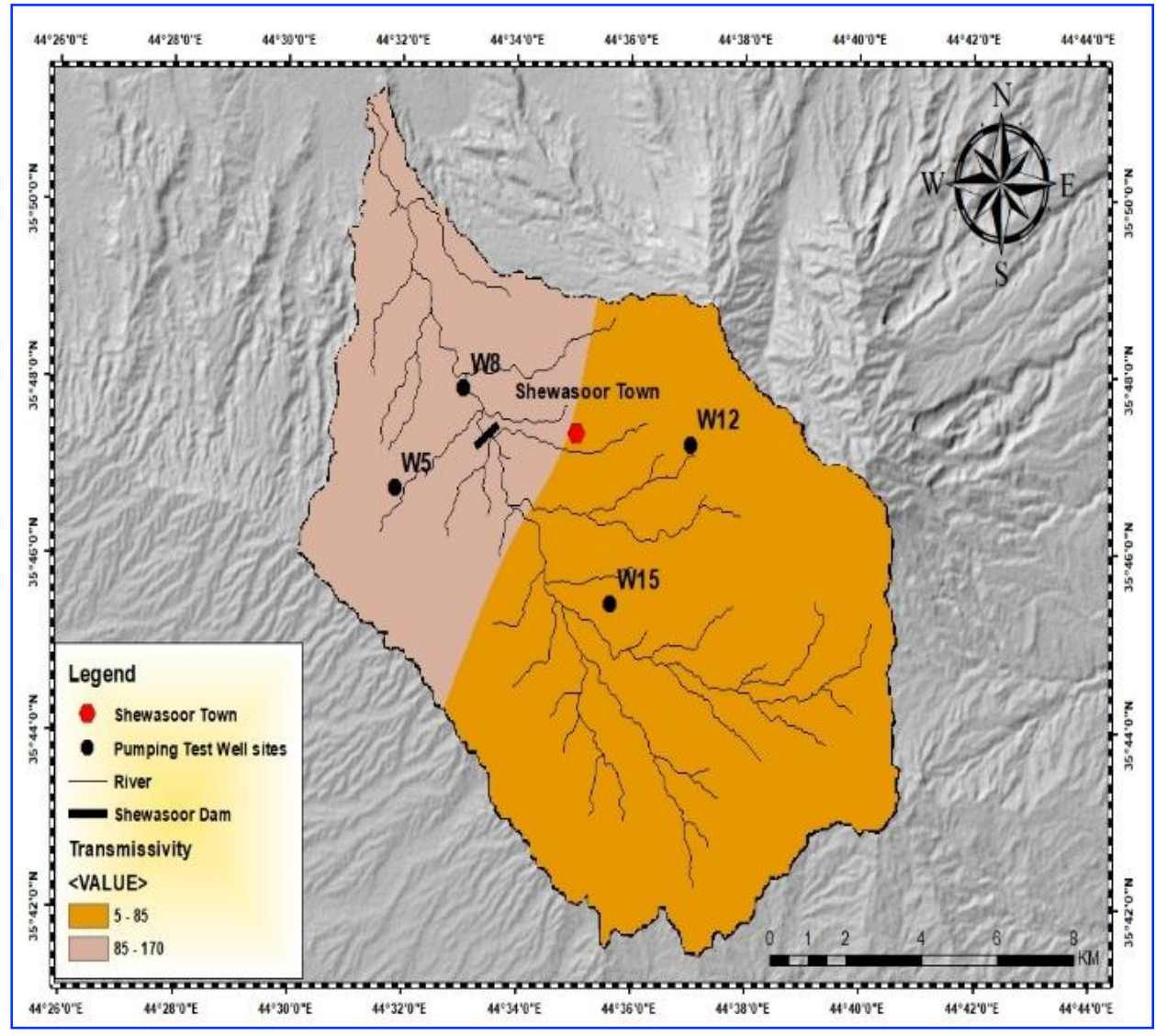

Fig. 6. Transmissivity map of the study area

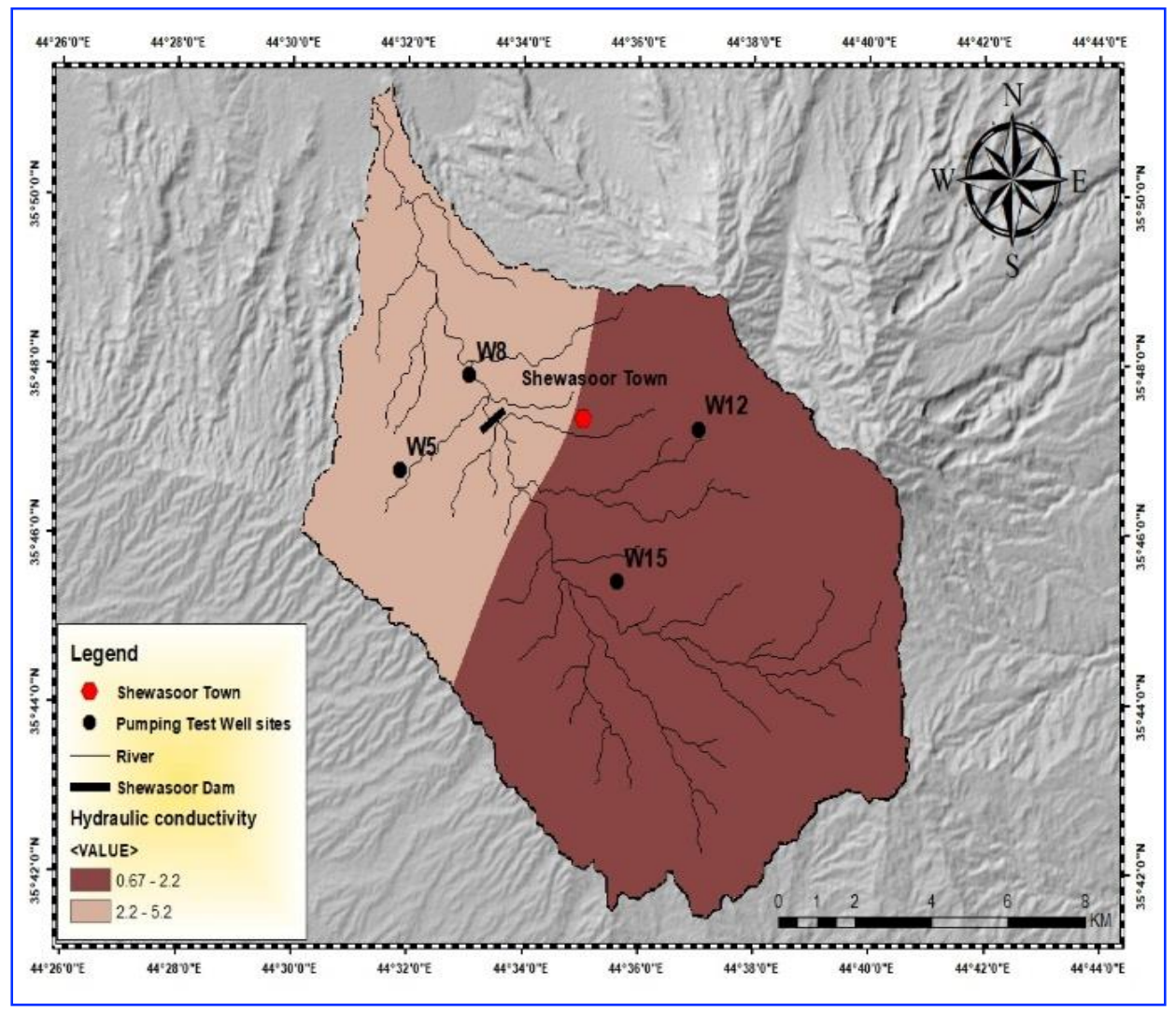

Fig. 7. Hydraulic conductivity map of the study area 


\subsection{Climatic Water Balance}

An important part of the hydrological cycle is climatological water balance and it has a relationship between the rainfall on the area and the amount of water lost with different patterns, (Domenico and Schwartz, 1998). The water balance equation based on the principle that inputs equal outputs (Todd and Mays, 1980). The input elements in the water balance are rainfall and snow (Table 4). The two outputs are matching by evaporation and transpiration. Evaporation defines as the process of losing water from water surfaces or from the soil. Transpiration is the process of losing water from plants. The two mentions processes called evapotranspiration that consists of (Potential evapotranspiration). Potential evapotranspiration is the water lost with enough quantity at the time while the quantity is determined when calculating the Actual evapotranspiration. Actual evapotranspiration is the highest rate or equal to the calculated evapotranspiration and it is the reference of the amount of water that wanted for germination purposes in the area, which has reflected the total annual proportion of rainfall to the annual total of evapotranspiration to identify the type of area according to this type. The inputs are equal to the outputs based on the flowing equation (Todd and Mays, 1980) (Table 5).

Table 4. The climatic water balance elements of the study area

\begin{tabular}{|c|c|c|c|c|c|c|}
\hline Months & rainfall (mm) & Pec (mm) & $\mathrm{AE}(\mathbf{m m})$ & SM (mm) & WS (mm) & WD (mm) \\
\hline Oct. & 43.9 & 87.64 & 43.9 & 0 & 0 & 43.74 \\
\hline Nov. & 74.6 & 26.61 & 26.61 & 47.99 & 0 & 0 \\
\hline Dec. & 99.5 & 10.16 & 10.16 & 100 & 37.33 & 0 \\
\hline Jan. & 120 & 5.66 & 5.66 & 100 & 114.34 & 0 \\
\hline Feb. & 92.9 & 8.48 & 8.48 & 100 & 84.42 & 0 \\
\hline Mar. & 104.2 & 21.77 & 21.77 & 100 & 82.43 & 0 \\
\hline Apr. & 70.6 & 51.18 & 51.18 & 100 & 19.42 & 0 \\
\hline May. & 14.7 & 120.38 & 14.7 & 0 & 0 & 105.68 \\
\hline June. & 0.7 & 206.73 & 0.7 & 0 & 0 & 206.03 \\
\hline July. & 0 & 281.54 & 0 & 0 & 0 & 281.54 \\
\hline Aug. & 0 & 254.61 & 0 & 0 & 0 & 254.61 \\
\hline Sep. & 7.2 & 164.13 & 7.2 & 0 & 0 & 156.93 \\
\hline Total & 628.3 & 1238.89 & & & 337.94 & 1048.53 \\
\hline
\end{tabular}

When calculating the water balance of the Shewasoor sub- basin for the period $2002-2019$ depending on $100 \mathrm{~mm}$. The amount of the soil reaches the saturation point (Al Forat Research Center and Design irrigation projects, 2000). The months Dec, Jan, Feb, Mar and Apr are the period of the water surplus which is the wet period is equal to $337.94 \mathrm{~mm}$ of the annual rainfall which equal to 629.3 $\mathrm{mm}$ and that equal $53.786 \%$ percentage.

$$
\mathrm{WS} \%=(\mathrm{WS} / \mathrm{P}) * 100
$$

$$
\text { WS } \%=(337.94 / 628.3) * 100=53.786 \%
$$

The surface runoff is included in the calculations of the water balance equation used in calculating the amount of groundwater recharge. The surface runoff of the study area is 138.5 depending on surveying final report of the Italian company which is constructed Shewasoor dam. The value of the surface runoff depending on the slope and nature of the ground surface (Ali, 2020). Groundwater Recharge (Gr) the amount of water, which percolates into the groundwater levels, was calculated and the results of groundwater recharge were as follows: $\mathrm{WS}=\mathrm{Gr}+\mathrm{Sr}, 337.94=\mathrm{Gr}+138.5=(4 . .911 /$ $628.3) * 100=31.742 \%$ from the rainfall percolated to recharge the groundwater in the study area. 


\subsection{Water Table Fluctuation Method (WTF)}

Water table fluctuation method is an estimated of groundwater recharge accomplishment by analyzing water-level fluctuations in the wells that have been monitored. This method based on the assumption that the measured groundwater level rise in these wells as a response from the addition of recharge to the groundwater table (Freeze and Cherry, 1979) (Table 5) and (Fig. 8). Recharges calculating by using the following equation (Healy and Cook, 2002): GR $=\mathrm{Sy} \times \Delta \mathrm{h}$ showed that the groundwater recharge is equal to $232.07 \mathrm{~mm}$ (Table 5) and (Fig. 9).
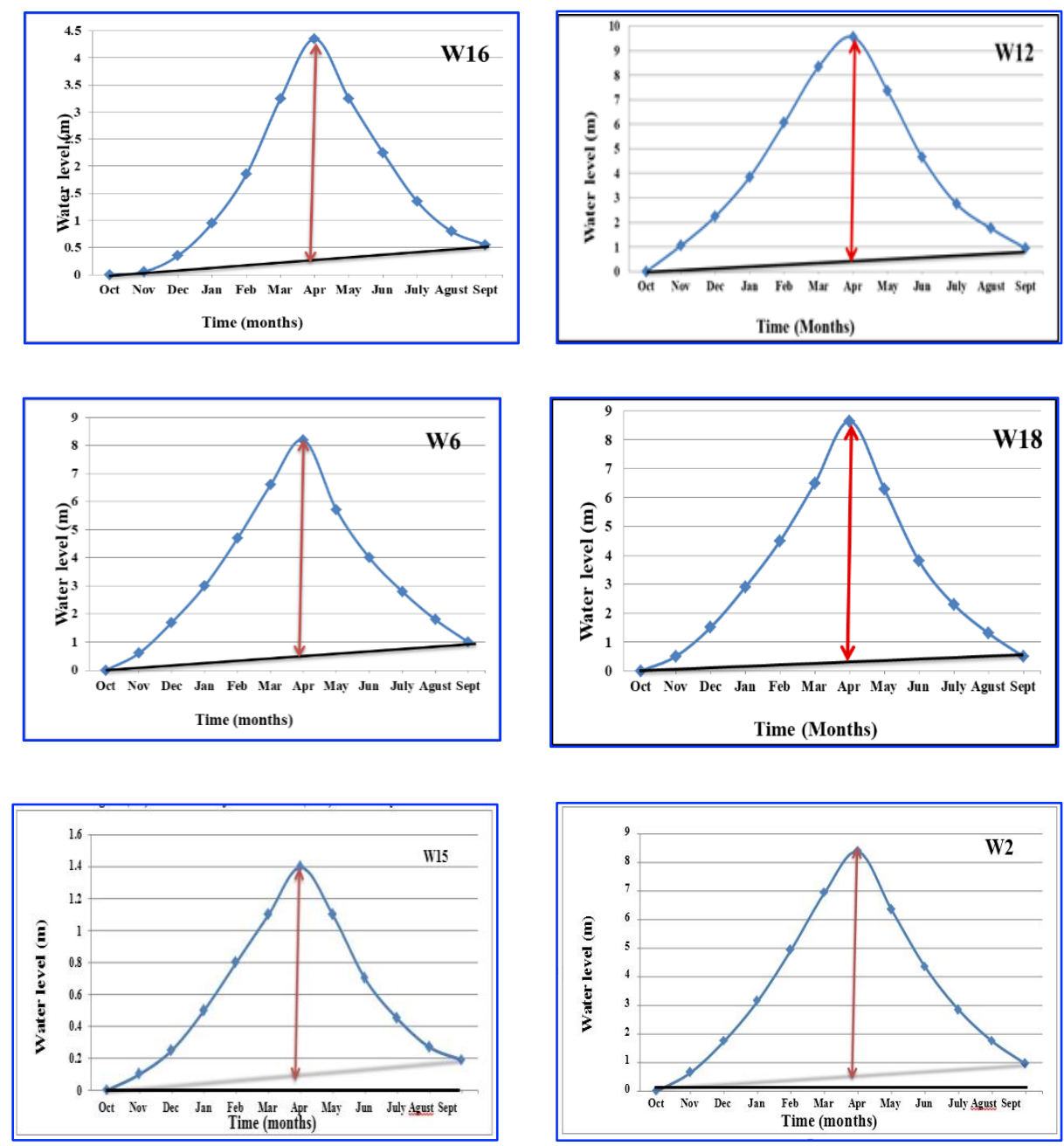

Fig.8. Groundwater level fluctuations in wells 16, 12, 6, 18, 15 and 2 in the study area

Table 5. Result of fluctuation of the groundwater balance in the study area

\begin{tabular}{lccc}
\hline Well No. & Sy & $\boldsymbol{\Delta h}(\mathbf{m})$ & $\mathbf{G R}(\mathbf{m m})$ \\
\hline W2 & 0.00137 & 8.4 & 11.508 \\
W6 & 0.00137 & 8.2 & 11.234 \\
W12 & 0.1325 & 9 & 1192.5 \\
W18 & 0.002 & 8.65 & 17.3 \\
W16 & 0.0278 & 4.35 & 120.93 \\
W15 & 0.0278 & 1.4 & 38.92 \\
Average & & & 232.065 \\
\hline
\end{tabular}




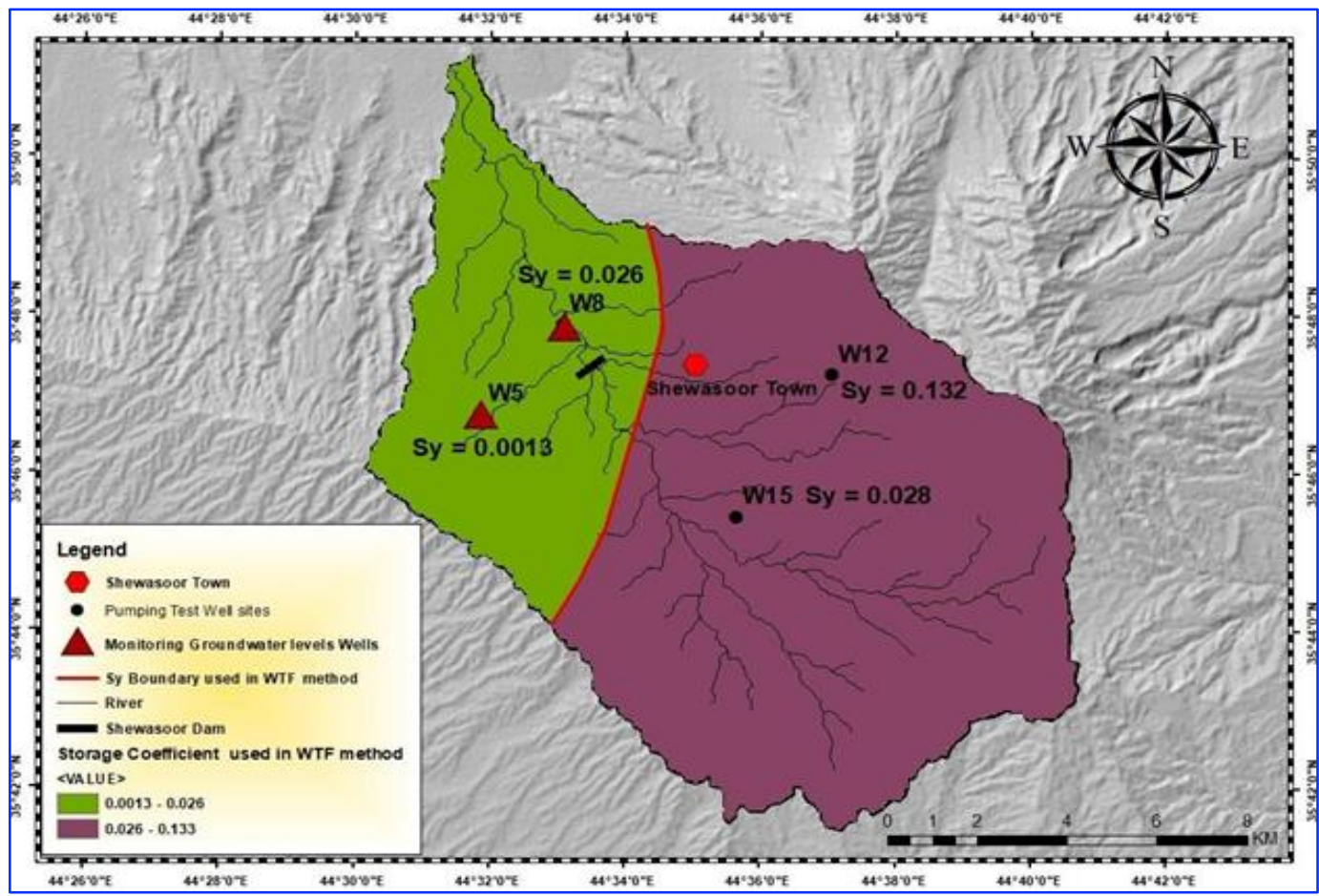

Fig.9. Average of specific Yield value used in WTF method

\subsection{Estimation of (Recharge and Discharge) Ground and Surface water in Shewasoor subbasin}

Groundwater resources management takes in consideration estimation of the major components of the groundwater budget, such as recharge and discharge. Depending on Theis (1940); Bredehoeft (2007) the size of groundwater resources is determined by the amount of captured discharge and the induced recharge, rather than by the rate of natural recharge. Groundwater always moves towards the lower head, this discharge area is always at a lower elevation than the water table where groundwater enters the system as recharge (Fitts, 2002). Groundwater flow of the study area was determined by using the Flow Net Analysis Method (Fig. 2). Groundwater flow calculated by the following equation (Ahmed et al., 2005; Raghunath, 2006):

$$
Q=T \text { iL and } i=\mathrm{dh} / 1
$$

Where:

i : Hydraulic gradient. dh: total head difference (m)

$\mathrm{L}$ : Length of the flow path $(\mathrm{m})$

$\mathrm{T}$ : Average of Transmissivity $\left(\mathrm{m}^{2} /\right.$ day)

$\mathrm{Q}$ : Discharge ( $\mathrm{m}^{3} /$ day)

1: Front length $(\mathrm{m})$

The major aquifers in the study area are (quaternary and Bi-Hassan), which extend to large areas as shown in the geological map. Depending on the results of the water budget obtained by the Italian report and WTF methods (31.742 and $36.953 \mathrm{~mm}$ ), respectively, (34.338 $\mathrm{mm}$ as an average) to estimate renewal groundwater recharge. Annual or renewal groundwater recharges quantity in the unconfined semi unconfined aquifer calculated based on equation (Raghunath, 2006):

$$
\text { Renewal storage }=\mathrm{A} \times \mathrm{G} . \mathrm{R}
$$

Where:

Renewal storage: Annual groundwater recharges quantity (m3/year)

A: Area of recharge region $\left(\mathrm{m}^{2}\right)$ 


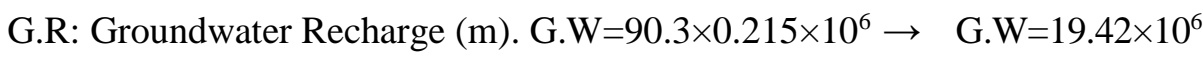

G.W $=19.42 \mathrm{MCM}$ Annual groundwater recharges in the study area

$\Delta \mathrm{s} \pm=\mathrm{G}_{\mathrm{in}}-\mathrm{G} . \mathrm{W}_{\text {out }} \rightarrow \Delta \mathrm{s} \pm=19.42-12.03$

$\Delta \mathrm{s} \pm=7.39 \mathrm{MCM}$

This value can be investing in the region and not exceeded to ensure that there is no depletion of groundwater storage in the region in line with the effects of climate change and the succession of dry seasons. After conducting the water balancing using the two methods mentioned above, as the first method was dependent on the elements of the climate and the second depended on the fluctuation of levels groundwater during the months of the water year, when comparing the two methods, the results were very close, despite the difference between the two methods, as the first method relied on inputs (rains) and outputs (evaporation and evapotranspiration) of water, while the second method relied on monitoring levels directly for a month and after making calculations and graphs between months. And the level shows that the wet period brings the largest amount of water into the basin, and after entering these values to calculate the recharge, it turns out that the recharge value in this method is 232.06 to calculate the water balance in this way, while the value of recharging in the first classical method was 199.44 and since the results of the two methods are very close, the average use of the two methods and its use in the general water budget 215.7.

\section{Conclusions}

pumping test experiments, shows there are two zones: The recharge areas and the discharge areas in which the values range from $140-170 \mathrm{~m}^{2}$ / day the hydraulic conductivity values are between 0.7 to $5.0 \mathrm{~m} /$ day between the two mentioned zones, while the type of aquifer is unconfined to semi-confined. The groundwater moves from the east, southeast, south and southwest (recharge areas) towards the northwest regions (discharge areas). The water surplus is equal to $333.94 \mathrm{~mm}$ which represents $53.8 \%$ of the annual rainfall value $(628.3 \mathrm{~mm})$ and the surface water is equal to $138.5 \mathrm{~mm}$ as a runoff. $199.44 \mathrm{~mm}$ (31.74\%) out of the annual rainfall is percolated to recharge the aquifers of Shewasoor, while water table fluctuation method WTF showed the groundwater recharge is $232.06 \mathrm{~mm}$, so can be said that the $215.8 \mathrm{~mm}$ is the average of the groundwater recharge in Shewasoor sub-basin. Finally, the amount of groundwater discharged from the study area is about 12 million m3 (MCM) and the renewal groundwater storage is 19.42 million $\mathrm{m} 3$ (MCM), which means there is 7.39 million $\mathrm{m} 3$ is groundwater can be invested as a safe investment. The area is under the influence of a climate ranging from semi-dry to semi-humid.

\section{Acknowledgements}

The authors are very grateful to the reviewers, Editor in Chief Prof. Dr. Salih M. Awadh, the Secretary of Journal Mr. Samir R. Hijab, and the Technical Editors for their great efforts and valuable comments.

\section{References}

Ahmed, A. M., Abdulrazak, M. I., \& Dawood, K. S., 2005. Hydrogeologic study for upper part of Diyala river basin, Groundwater studies center, General Directory of water resources Management, Ministry of Water Resources.

Al Forat Research Center and Design irrigation projects., 2000. A technical report for drilling wells in Alton Copry -Daramman in Kirkuk Governorate. Ministry of Water Resource, 63.

Al-Hayali, H. D., Al-Tamimi, O. S. I., \& Hamamin, D. F., 2021. Identification of vulnerable zones for groundwater using a GIS-based DRASTIC Technique in Shwan Sub-basin, North-Iraq. Iraqi Journal of Science, 18571597. 
Al-Naqash, A. B., Ismaeel, S. K., Hassan, A. H., \& Rahey, K. M., 2003. Evaluation study of wells operation of national campaign project for watered wells drilling in Kirkuk governorate. Technical Final Report, Ministry of Irrigation, 185.

Ali, S. M. M., \& Al-Tamimi, O. S. I., 2019. Hydraulic characteristics of the aquifer up Al-Khassa Dam Sub-Basin Kirkuk, NE Iraq. Iraqi Journal of Science, 60(5), 1085-1094.

Domenico, P. A., \& Schwartz, F. W., 1998. Physical and chemical hydrogeology, 506, New York: Wiley.

Engineering Consulting Bureau, 2010. Hydrology and hydraulic final report, which involves hydrological model, peak discharge calculations, and sediment yield determination, 58.

Fitts, C. R., 2002. Groundwater science. Elsevier.

Freeze, R. A., \& Cherry, J. A., 1979. Groundwater Prentice-Hall Inc. Eaglewood Cliffs, NJ.

Healy, R. W., \& Cook, P. G., 2002. Using groundwater levels to estimate recharge. Hydrogeology Journal, 10(1), 91-109.

Hem, J. D., 1985. Study and interpretation of the chemical characteristics of natural water, Department of the Interior, US Geological Survey, 2254.

Jassim, S. Z., \& Goff, J. C., 2006. Phanerozoic development of the northern Arabian Plate. Geology of Iraq, 3244.

Mendosa, F.G., Steenhuis, S.T., Todd Walter, M. and Parlange, J.-Y. 2003. Estimating basin-wide hydraulic parameters of a semi-arid mountainous watershed by recession flow analysis. Journal of Hydrology, 279, 57-69.

Moharir, K. N., Pande, C. B., Singh, S. K., \& Del Rio, R. A., 2020. Evaluation of analytical methods to study aquifer properties with pumping test in Deccan basalt region of the Morna River basin in Akola District of Maharashtra in India. In Groundwater hydrology. Intech Open.

Raghunath, H. M., 2006. Hydrology: principles, analysis and design. New Age International.

Theis, C. V., 1940. The source of water derived from wells. Civil Engineering, 10(5), 277-280.

Tizro, T. A., Voudouris, K. S., \& Kamali, M., 2014. Comparative study of step drawdown and constant discharge tests to determine the aquifer transmissivity: the Kangavar aquifer case study, Iran. Journal of Water Resource and Hydraulic Engineering, 3(1), 12-21.

Todd, D. K., \& Mays, L. W., 1980. Groundwater Hydrology. John Willey \& Sons. Inc., New York, 535.

Todd, D. K., \& Mays, L. W., 2004. Groundwater hydrology. John Wiley \& Sons.

Waspodo, R. S. B., Prakusya, A. A., \& Dewi, V. A. K., 2020. Hydrogeology study and determination of aquifer distribution using geoelectrical schlumberger method in subang regency. In IOP Conference Series: Earth and Environmental Science. 542 (1), 012057. 